\title{
The Dangers of Fiscal Decentralization and Public Service Delivery: a Review of Arguments
}

\author{
Helge Arends
}

Published online: 26 March 2020

(C) The Author(s) 2020

\begin{abstract}
The prevailing belief is that local governments, which are closer to their citizens, can deliver public goods much more efficiently than a central government can. Yet skeptics argue that fiscal decentralization can be dangerous. The underlying motivation of this article is to review the basic rationale behind decentralizing public services from the perspective of three main controversies emerging from the literature on decentralization: (in)efficient, (un)equal, and (un)accountable service provision at the local level. For illustrative purposes, this review focuses on two complex and socially important sectors, health and education. The overall conclusion is that the dangers of decentralization are highly relevant to local public service provision, although there is evidence supporting both the decentralization-enthusiastic and the decentralization-skeptical views. When decentralizing public services, reformers should know the specificities of the public service, the local context, and the effects of the design of fiscal relations like the backs of their hands. If things go wrong, recentralization should be an option.
\end{abstract}

Keywords Health decentralization - Education decentralization · Literature review $\cdot$ Recentralization 


\section{Die Gefahren der Dezentralisierung und öffentliche Dienstleistungserbringung: eine Durchsicht der Argumente}

Zusammenfassung Die Ansicht, dass subnationale Regierungen aufgrund ihrer Nähe zum Bürger öffentliche Güter effizienter bereitstellen können als die Zentralregierung, ist weit verbreitet. Skeptiker argumentieren jedoch, dass Fiskaldezentralisierung Gefahren birgt. Die Motivation dieses Beitrags ist es, den Grundgedanken der Dezentralisierung von öffentlichen Dienstleistungen aus der Perspektive von drei zentralen Kontroversen in der Dezentralisierungsliteratur zu beleuchten: die Gefahren der (in)effizienten, (un)gleichen und (un)verantwortlichen Bereitstellung von Dienstleistungen durch subnationale Ebenen. Zur Veranschaulichung liegt der Fokus auf der Dezentralisierung zweier komplexer Politikfelder, nämlich Gesundheit und Bildung. Die Hauptaussage ist, dass die Gefahren der Dezentralisierung hochrelevant für die Bereitstellung lokaler Dienstleistungen sind, auch wenn die Empirie Argumente sowohl der Dezentralisierungsenthusiasten als auch der Skeptiker unterstützt. Wenn die Dezentralisierung öffentlicher Dienstleistungen vorgenommen wird, dann sollten Reformer die Eigenheiten des Sektors, den lokalen Kontext und die aus dem fiskalpolitischen Design entstehenden Anreize wie ihre Westentasche kennen. Wenn Fiskaldezentralisierung schiefgeht, sollte Rezentralisierung in Betracht gezogen werden.

Schlüsselwörter Gesundheitsdezentralisierung · Bildungsföderalismus ·

Literaturbericht $\cdot$ Rezentralisierung

\section{Introduction}

Over the past decades, mistrust in the abilities of central governments to efficiently provide public services has caused a wave of fiscal decentralization reforms. The belief is that local governments, which are closer to their citizens, can deliver public goods much more efficiently. However, there are reasons to believe that lower tiers of government could encounter severe challenges in adequately exercising fiscal competences. Skeptics argue that fiscal decentralization could have negative effects on human wellbeing. In Germany, major management errors and rapidly escalating costs in the context of large infrastructure projects in the federal states of Hamburg (Elbe Philharmonic Hall), Brandenburg (Willy Brandt Airport), and BadenWuerttemberg (Stuttgart railway project) have revealed a latent debate on allegedly lacking managerial capacities and deficient citizen responsiveness at the lower levels of government in the German federal system (see Kostka and Fiedler 2016).

As early as the 1990s, management and planning problems observed at the subnational level gave rise to a debate on the potential "dangers of decentralization." This debate signaled the fundamental risks decentralization processes could pose, in particular with regard to reduced efficiency, increased regional inequalities, and weakened local accountability (Prud'homme 1995; Tanzi 1996). These dangers may be especially eminent when the aim of decentralization reforms goes beyond enhancing "traditional competences" of subnational governments and promotes the passing 
down of complex service provision tasks such as healthcare and education. In German federalism, a chronic underinvestment in educational infrastructure is attributed to the fact that the federal states responsible are constantly short of money and have little autonomy to improve their fiscal situation (Schmidt 2007). As a consequence, the third Grand Coalition led by Chancellor Angela Merkel recently enhanced the federal government's positioning to get involved in the decentralized education sector and agreed on the "digital pact," through which the federal government provides funds to the federal states to improve digital infrastructure in schools (Scheiter and Lachner 2019). It is suspected that the federal government does not trust the Länder to provide equitable and quality services in a complex sector such as education.

However, in spite of these doubts on the merits of decentralization, major donor organizations and policy advisors continue to promote decentralization as a remedy for the inefficient provision of services by central governments in complex sectors such as health and education, especially in countries with an extremely weak governance structure, such as Iraq (see World Bank 2016).

This suggests that the dangers of decentralization remain highly relevant to the debate on the quality of public service provision. Therefore, the underlying motivation of this article is to review the literature dealing with the relationship between fiscal decentralization and the provision of public services from the perspective of the risks a decentralization reform could imply. In a first step, the key theoretical contributions providing the ground for the basic rationale behind fiscal reforms will be presented. The contributions are primarily drawn from the "first-generation theory of fiscal federalism," which has its origins in the 1950s and assumes the public servant to be a welfare maximizer, serving the good of the people. In a second step, I look at the literature containing arguments that challenge the basic rationale of fiscal decentralization and cast doubt on the positive effect of fiscal decentralization and public service delivery. These more nuanced contributions usually form part of the "second-generation theory of fiscal decentralization," which emerged during the 1990s and assumes that the self-interest of the public servant seldom matches the interest of the general population (Qian and Weingast 1997). The reviewed literature will be grouped according to three main questions corresponding to three major dangers that are recurrent in the literature:

1. Efficiency: Does fiscal decentralization make public service delivery less efficient?

2. Equality: Does decentralization make public service delivery more unequal?

3. Accountability: Does decentralization make public service delivery less accountable?

In a third step, I will provide reflections on the practical implications of the presented literature with regard to the characteristics of the decentralized public service, the contextual conditions, and the design of fiscal relations.

I evaluate the relevance of these dangers to the provision of local public goods related to health and education, as these are two sectors generally considered highly complex, which are fundamental to the wellbeing of society as a whole and to contributing to national objectives (Boadway and Shah 2009, p. 397). This way, the review goes beyond a growth-centered discussion and puts the spotlight on the effects of decentralization on the quality of public services and thus on its immediate 
impact on human development. Moreover, while I focus on a review of the theoretical arguments provided, I also give a brief overview of the empirical work undertaken so far and identify research gaps. The research disciplines reviewed are diverse and relate to both fields, political science and economics. Many contributions can be located in the fields of public choice and political economy as they put political processes and the behavior of political agents at the center. Some of the reviewed arguments also relate to the literature dealing with problems of information and to the area of democratic theory. From a sectoral perspective, the empirical literature mainly relates to health and education research.

The overall conclusion of this review is that the dangers of decentralization are highly relevant to local public services in terms of the efficiency, equality, and accountability of service provision. Although there is evidence to support both the decentralization-enthusiastic and the decentralization-skeptical views, there are means of mitigating risks: When decentralizing public services, reformers should know the specificities of the respective public service, the local context, and the effects of the design of fiscal relations like the backs of their hands. If things go wrong, recentralization is a viable option.

\section{The Rationale Behind Fiscal Decentralization: a Brief Reminder}

In his Theory of Public Finance, Richard Musgrave defines three core objectives of public financial and fiscal policy: a) the need to ensure stable prices and full employment ("stabilization branch"), b) the importance of providing for a socially acceptable distribution of income and wealth ("distribution branch"), and c) the efficient allocation of public resources for the provision of public goods ("allocation branch"; Musgrave 1959). While scholars generally agree that stabilization and distribution should remain in the hands of the central government (see Oates 1968), the argument for fiscal decentralization is a response to the "fundamental problem of the provision of public goods" encountered by the allocation branch. Samuelson $(1954,1955)$ defines this problem as the inability of the public sector to determine the efficient level of expenditure on public goods. The nature of public goods (Ostrom 1990; Rondinelli et al. 1989, pp. 63-65) as well as merit goods ${ }^{1}$, namely their nonexcludability from consumption (Olson 1969, p. 481), makes it nearly impossible to get an exact picture of the preferences of consumers. A self-interested consumer would have an incentive to understate the value ascribed to the consumption of a particular public good (Samuelson 1954), rendering it infeasible to adequately tax them. Consequently, public goods are not provided in an efficient manner.

As a first major idea to solve this problem, Tiebout (1956) proposed a marketlike mechanism to reveal consumers' true preferences. The core assumption behind Tiebout sorting is the notion that consumers are mobile and move to jurisdictions where they can benefit from their preferred level and quality of a particular public

\footnotetext{
1 Merit wants refer to those wants that, in principle, could be satisfied by the private market but which are of such importance that the government takes on the role of providing the service to all members of society (Musgrave 1959, p. 13).
} 
service, provided at the price they are willing to pay. Thus, creating a multitude of local communities each providing a different bundle of public services increases choice in the public goods market. Local managers compete for an efficient population size within their jurisdictions (Inman and Rubinfeld 1997, p. 45). With a sufficient number of jurisdictions and sufficiently high variation in the levels, costs, and kinds of services provided, the provision of public goods approaches an efficiency level comparable to that of privately provided goods (Tiebout 1956, p. 420).

Clearly, Tiebout sorting is based on strong assumptions. Most importantly, it requires fully mobile citizens to have complete knowledge of the revenue-expenditure packages offered by all local governments. Yet the Tiebout model has sparked a debate on competition between localities and has given rise to arguments either related to the "race to the bottom" or "race to the top" hypothesis between local authorities (Busemeyer 2008; Turner and Rowe 2015).

The second and probably more influential rationale for fiscal decentralization was brought forward by Oates (1972). He argued that even if the preconditions needed for Tiebout sorting to properly function were not present, decentralization would still be a powerful instrument through preference matching. While it may be the case that for some public goods, such as clean air, a uniform-i.e., central government-provision is inevitable, many public goods, such as regional transportation systems or forestry services, should be provided in a differentiated form, taking account of the specific characteristics of a country's regions (Oates 1999, p. 1122). A central government "one size fits all" approach to the provision of public services would lead to underprovision or overprovision in some regions (Tanzi 1996, pp. 298-300). According to Oates, the central government suffers from imperfect information and cannot grasp the full complexity of the distribution of preferences. Local governments benefit from the proximity to their constituency and can better assess what their people really want, what they are willing to pay, and how much the provision of services will cost (Oates 2005, pp. 253-259). Thus, local policy makers tailor public services to local preferences, which increases efficiency of public resource allocation in the aggregate.

Even when the central government attempts to respond to territorial differences, such as through the creation of field offices (see Martinez-Vazquez et al. 2017, p. 1097), Oates (2005, p. 253) argues that local policy makers would still have an advantage because they interact more comprehensively with "their" constituency and remain in possession of superior local knowledge. Also, a territorially differentiated provision at the central level would be difficult to achieve because it is politically difficult to be more generous to one region than to others. Hence, "preference matching" would promote efficient allocation of public services.

A third argument presented by Breton (1987) and Salmon (1987) underscores the issue of competition. In contrast to Tiebout sorting, which is based on the idea of citizens "voting with their feet" (the exit option), the idea of yardstick competition underscores the citizens' ability to compare the performance of "their" local government with that of neighboring or otherwise similar governments and to punish their local leaders in the context of local elections if necessary (the voice option). Afraid of not being reelected, local leaders would try to improve the quality of services delivered while keeping costs as low as possible. For the mechanism to work, Salmon 
(1987, p. 32) stresses the importance of an environment that enables local governments to enter into horizontal competition with each other for the best efficiency outcomes. A precondition is the use of available comparative performance data, motivation on the part of citizens to hold governments to account, and functioning local democratic processes.

A fourth major argument underscores the issue of innovation. Local jurisdictions could serve as laboratories of experimentation: A high number of local governments, which implies diversity among governing political parties and different organizational cultures, causes a variety of policies to be applied (Pierson 1995, p. 456). According to this argument, policy innovations that have proven successful in one jurisdiction would then be diffused to other localities so that they ultimately become the national standard (De Vries 2000, p. 197). Policy experimentation at the local level is less risky than innovation at the central government level, since failure of the applied innovation would affect a smaller number of people (Vanberg and Kerber 1994).

Among scholars of various disciplines, the arguments presented above have sparked considerable enthusiasm about fiscal decentralization, initiating a vast number of decentralization reforms. In the wake of such reform enthusiasm, in particular in the 1990s, some scholars-including Rémy Prud'homme with his essay on The Dangers of Decentralization - shared their concern that fiscal decentralization might bring with it a range of problems, canceling out the potential positive effects of fiscal decentralization presented herein.

\section{Fiscal Decentralization, Public Service Provision, and Three Dangers}

While the aforementioned "first-generation theory of fiscal federalism" (see Oates 1972; Rubinfeld 1987) generated the underlying rationale for fiscal decentralization, a "second-generation theory of fiscal federalism" (Qian and Weingast 1997) deals with more detailed questions, including institutional design, intended and unintended side effects, and the enabling of conditions for successful fiscal decentralization. While the first generation assumes the public servant is a welfare maximizer, the second generation argues that public servants at the local level may have other interests than promoting the public good, potentially compromising the beneficial effects of decentralization (Khan et al. 2017, p. 328).

In line with the latter, Prud'homme (1995) groups the dangers of decentralization according to Musgrave's three objectives of public financial and fiscal policy: the negative effects on macroeconomic stability, possible detrimental effects on efficiency in service delivery, and the risk of increasing regional disparities in income. Furthermore, discussion of these dangers of decentralization puts the spotlight on a previously underreported additional danger, namely the danger of local corruption and collusion (see Rodríguez-Pose and Gill 2005, p. 406). I will review the dangers of decentralization with regard to public service delivery according to the following 
three dimensions: a) inefficient service delivery; b) unequal service delivery, and c) unaccountable service delivery. ${ }^{2}$

\subsection{Does Fiscal Decentralization Make Public Service Delivery Less Efficient?}

Efficiency is usually discussed in two dimensions: Allocative efficiency refers to the adequate allocation of public services so that they match local demand. In particular, Tiebout sorting and preference matching are two concepts that are supposed to bring about a more exact allocation of resources according to the true preferences of the population. Production efficiency, in turn, is present when a given quantity and quality of public service is being produced and provided at the lowest costs (Litvack et al. 1998, p. 20). ${ }^{3}$ The concepts of yardstick competition and the notion of laboratories of experimentation both refer to possible improvements in production efficiency through decentralization - although the former in particular is also relevant for allocative efficiency. Decentralization skeptics have brought forward concerns with regard to both types of efficiency effects of decentralization.

In terms of allocative efficiency, the most prominent argument is the danger of interjurisdictional spillovers. Spillovers or externalities refer to the situation when the benefits or costs of public service provision are imposed on outside actors (Blom-Hansen et al. 2016, p. 816). For instance, services provided by city-center governments such as free parks that are used by citizens from the entire metropolitan area, including people not belonging to the jurisdiction and thus who do not pay local taxes, tend to suffer from uncompensated externalities. Uncompensated benefits to the outside population can lead local decision makers to underprovide local services (Olson 1969, p. 482). ${ }^{4}$

Another concern relates to a possible race to the bottom between local governments. The Leviathan hypothesis brought forward by Brennan and Buchanan (1980, p. 184) holds that competition for mobile production factors forces local governments to keep local taxes and spending as low as possible and thus to tame the expansion of the public sector. While Oates (1985) rejects the hypothesis on empirical grounds, the concern of decentralization skeptics is that local governments enter into "destructive interregional competition." For example, they would lower spending or loosen essential regulations, such as environmental standards, to such levels that adequate provision of essential public service cannot be guaranteed (Cumberland 1981; Kunce and Shogren 2007).

However, in recent years overspending rather than underspending has been considered a danger to macroeconomic stability and efficiency. The notion that local governments may get bigger and bigger gave rise to the flypaper-effect argument

\footnotetext{
${ }^{2}$ Because I examine the dangers related to public service delivery and not economic growth, regarding which the stability dimension would be particularly relevant and should be discussed separately, I discuss the issue of subnational borrowing in terms of its effect on service delivery efficiency.

3 This is the input-oriented definition of production efficiency.

4 The issue of spillovers led Olson (1969, p. 479) to formulate the "principle of fiscal equivalence." Every public good would have its own individual functional unit with a unique boundary. This way, the risk of spillovers would be minimized, and Pareto-efficient service provision would be ensured.
} 
formulated by Courant et al. (1979, p. 6), who hold that spikes in intergovernmental transfers cause increased public expenditure much more rapidly than spikes in local income do. Local officials avoid reducing taxes even though they receive additional nonmatching grants. The underlying explanation is that local populations are unable to note the marginal price of an increase in revenues from transfers because these are perceived as additional funds from external resources (Hines and Thaler 1995).

The fear that local governments have incentives to become overindebted stems from the debate about soft budget constraints. Local governments face soft budget constraints when they can expect to be bailed out by the central government in case of debt default. Thus, the disciplining force of the capital market is ineffective, and local governments would accumulate ever increasing deficits. As Kornai et al. (2003) note, central governments can encounter severe limitations in credibly "selling" their nobailout position because letting an (important) local government default can imply severe welfare (e.g., in the form of high unemployment) and reputational costs (e.g., in the form of local officials blaming the central government for not having taken on responsibility). The result would be that local governments spend way above the efficiency threshold (see Goodspeed 2002).

The structure of local government revenues is considered to be important for both allocative and production efficiency. The fiscal illusion hypothesis holds that when citizens who are also voters and taxpayers cannot make the link between taxes paid and benefits received, they are less likely to sanction local politicians for bad quality in service delivery. When local revenues are dominated by grants from higher levels of government or by tax-sharing schemes, citizens perceive public services to be funded and provided from outside the local jurisdiction. This weakens the agency relationship between the local population and local officials (Weingast et al. 1981). Rodden (2003, p. 724) presents evidence that suggests that local governments with strong local revenues spend public resources more efficiently.

With regard to production efficiency, the most extensively discussed issue relates to scale economies. Small local governments are considered to suffer from high fixed costs in comparison to the volume of public services delivered (Blom-Hansen et al. 2016, pp. 813-816). For instance, in China, India, and Brazil, the devolution of tasks has substantially increased bureaucratic costs, caused by the duplication of basic administrative functions (Rodríguez-Pose and Gill 2005, p. 414). Although it has been stressed that population size matters most, the volume of public service provided and the dispersion of population over a certain territory are key to the issue of scale economies as well (Bel and Warner 2016, p. 93).

Closely related, one concern allegedly diminishing the production efficiency of public service delivery is the issue of weak administrative capacities at the local level. Prud'homme (1995, p. 210) argues that central government bureaucracies work far closer to the technical production frontier than local bureaucracies do. On the one hand, central governments can attract more qualified staff primarily because they have better career opportunities to offer. In fact, decentralization reform has encountered some opposition from health workers and teachers in several countries, as these groups did not want to give up privileges granted from central government employment schemes (Blair 2000, p. 27). On the other hand, central government can invest more in technology and innovation, putting its government in a better position 
to tackle complex service delivery issues (Martinez-Vazquez and Timofeev 2010, p. 603). Tanzi (1996, p. 303) holds that in particular, financial management may pose a challenge to local governments. With fiscal decentralization, local governments come to manage substantially larger amounts of public funds, which may overburden local financial management and auditing systems. In fact, the issue of insufficient administrative capacities is likely to be especially pronounced in highly technical and complex sectors, such as health and education. These sectors need a substantial amount of specialized knowledge, capital, and technological investments as well as general planning capacities, which may be more limited at the local level. For example, in health there may be a risk of inefficiently located health facilities, inefficient pricing when purchasing inputs, increased complexity of administrative paperwork, and even service duplication (Jiménez-Rubio and García-Gómez 2017, p. 70). A perceived inefficient territorial allocation of human resources and hospitals was one key reason why Danish and Norwegian health systems embarked on a path to recentralization, enhancing the roles of the regional and central levels in healthcare planning (Arends 2017b, p. 150).

With regard to the empirical evidence, it becomes clear that although the fiscal decentralization argument is essentially about efficiency in public service delivery, the larger part of the literature concentrates on the effects of decentralization on gains in economic development (Díaz-Cayeros et al. 2014, p. 81). Furthermore, as the amount of research on the topic increases, the evidence becomes increasingly inconclusive (see Aray 2017; Goel et al. 2017, p. 171; Martínez et al. 2018, pp. 726-727; Ramírez et al. 2017, p. 408), suggesting high dependence of the results on the level and period of analysis, method, selection of variables, and concept of decentralization applied.

With regard to the two main public services emphasized here, Channa and Faguet (2016) conclude that studies on the effect of fiscal decentralization on health and education outcomes, which apply the most sophisticated methods, tend to confirm a positive effect. This is particularly true for the education sector. More mixed results can be found in terms of healthcare performance, where there is even evidence suggesting a negative effect (Martinez-Vazquez et al. 2017, p. 1105).

One recurring issue in the discussion on public sector performance is the differentiation between developed and developing nations. Hanushek et al. (2013) analyze the effect of cross-country differences in school autonomy related to academic curricula, personnel selection, and budgets on PISA scores and find that the effect of autonomy is positive in high-income countries, while school autonomy negatively affects student achievements in middle-income and lower-income countries. Country-specific studies in education seem to confirm this difference in effects, as positive effects of some aspects of school autonomy tend to be recorded in developed economies such as the United Kingdom (Clark 2009), Norway (Naper 2010), and Switzerland (Barankay and Lockwood 2007), while nil or negative relationships are found in developing countries, such as in several Latin American countries (Prawda 1993). With regard to health, two recent surveys (Cobos Muñoz et al. 2017; Dwicaksono and Fox 2018) dealing with the effect of decentralization on healthcare performance in middle-income and lower-income economies add to the complexity of the issue. Cobos Muñoz et al. (2017) hold that in terms of the effect of fiscal 
decentralization on health outcomes, such as infant mortality and life expectancy, decentralization has had a conducive effect. Dwicaksono and Fox (2018) show that the literature is inconclusive when it comes to the effect on performance indicators, such as immunization rates or the attendance of births by skilled health personnel. While most reviews focused on quantitative studies, Cobos Muñoz et al. (2017) also took the vast qualitative literature on the issue into account, concluding that quantitative research seems to be considerably more optimistic than qualitative analyses, which, in turn, stress detrimental effects on the management of human resources, medication, and equipment. The latter view is also supported by the current discussion on recentralization in various developed countries as recorded by Saltman (2008). One frequently cited example of recentralization is Italy, where the central government introduced hospital recovery plans including, for example, closing down small hospitals in order to better benefit from economies of scale and to make the allocation of human resources more efficient (Mauro et al. 2017). The case of Spain exemplifies the difference between the decentralization of spending and revenue competences. Jiménez-Rubio and García-Gómez (2017) cite evidence suggesting that fiscal decentralization is negatively associated with infant mortality in Spanish regions that are characterized by a high degree of fiscal autonomy, ultimately supporting the fiscal illusion hypothesis.

Finally, the current literature reveals one important gap between theory and empirics: Studies dealing with the effect of decentralization on the performance of public goods provision, such as health and education, suffer from a misconception of the notion of efficiency. The bulk of the research looks either at the effect of fiscal decentralization on health and education spending, i.e., the input side, or at the outcome of services, i.e., the output side. This is surprising because, as stated, the major promise of fiscal decentralization is improved efficiency, which relates to an integrated view of an input-output relationship in specific policy areas.

The few studies that looked at the effect of fiscal decentralization and efficiency using the data envelopment analysis (DEA) method (see Cooper et al. 2006) suggest a differentiated view. Martínez et al. (2018) conclude that fiscal decentralization has a negative effect on the input-output relationship with regard to economic growth. Arends (2017b) argues that while spending decentralization tends to reduce healthcare efficiency, tax-based decentralization increases efficiency. Adam et al. (2014) suggest an inverted U-shaped relationship between decentralization and DEA efficiency in healthcare and education.

General conclusions on the validity of the above arguments are scarce because the existing research is seldom comparable and uses different specifications of decentralization, applies different methods to diverse contexts, and uses a divergent set of control variables. Some general trends relate to the important distinction between developed and developing countries, between tax and spending or transfer-based decentralization, and between different sectors that are being decentralized. Finally, there is a misconception of the term efficiency, with most researchers concentrating on inputs or outputs but not on the input-output relationship of public service delivery. 


\subsection{Does Decentralization Make Public Service Delivery More Unequal?}

A smaller body of literature revolves around the question of whether fiscal decentralization increases regional inequalities. This is an important question, as social inequalities are subject to major public and social debates. Many decentralization enthusiasts argue that centralized countries are more prone to increasing inequalities. Shankar and Shah (2003) find that the dispersion of income in federal countries reduces over time ("sigma convergence"). They argue that because territorial disparity is politically risky in federal systems, as it increases the probability of secession of particular regions, central government policy makers may have a strong incentive to ensure regional equality. In addition, since national parties depend on electoral success in all regions, they focus on equal regional development. Finally, the authors hold that federal state politicians are more accountable to the local electorate and pursue more developmental policies than central government politicians do.

Focusing only on the fiscal dimension of decentralization and almost exclusively emphasizing inequalities in economic development, some have argued that decentralization leads to lower regional inequalities because it initiates a catch-up effect: Those regions with lower initial levels of economic development show relatively higher growth rates than those regions with higher initial levels of development ("beta convergence"; Canaleta et al. 2004, p. 88) because less developed regions benefit more from decentralization as they are further away from the efficiency frontier (Lessmann 2012, p. 1368). Others hold that because of strong local electoral accountability relations, local politicians from poorer regions have stronger incentives to engage in "developmental policies" (Qian and Weingast 1997).

On the contrary, Prud'homme (1995, p. 203) emphasizes that decentralization could be a "mother of segregation." In decentralized systems there is no central authority pursuing a redistribution of fiscal resources from fiscally strong to fiscally weak regions. Richer regions tend to benefit from advantageous initial conditions such as better developed infrastructure, a better educated work force, and a stronger tax base, and have better access to production factors such as credit (Cai and Treisman 2005). Also, revenue-richer localities can offer more attractive tax conditions to businesses (Liu et al. 2017, p. 252). This way, they attract even more private sector investment. Furthermore, poorer regions are weaker when it comes to exploiting economies of scale from service provision and are assumed to suffer from weaker local governance structures, making it difficult to reap the assumed efficiency gains of decentralization (Zhang 2006). In these circumstances, decentralization perpetuates preexisting inequalities and inhibits beta convergence.

Inequalities can also stem from different degrees of political influence. Different local jurisdictions may find themselves competing for resources and in general for attention from the central government. Economically and politically powerful regions can obtain preferential treatment from the central government in terms of policy initiatives, general political support, and fiscal transfers (Rodríguez-Pose and Gill 2005, p. 412), as is the case for China (Liu et al. 2017, p. 253). Moreover, the central government may have a stronger interest in bailing out important jurisdictions to maintain macroeconomic stability or to avoid being blamed by the electorate for inaction. 
There is a substantial body of empirical literature investigating the relationship between decentralization and inequalities in terms of economic development. It consists of single-country case studies and cross-country studies looking separately at developed and developing country groups or at both groups together (Lessmann 2012, p. 1369). However, the direction of the effect on regional inequalities, just as is the case with the efficiency literature, depends on the method applied and the sample investigated. Country-case studies usually hint at an inequality-increasing effect of decentralization. Cross-country studies display a negative association when developed countries are compared and a positive association when developing countries are investigated (Kyriacou et al. 2015; Rodríguez-Pose and Ezcurra 2010). Earlier studies such as those of Ezcurra and Pascual (2008), Lessmann (2009), and Shankar and Shah (2003) find optimistic results when it comes to the inequalityreducing effect of decentralization or federalism, while later studies such as those by Lessmann (2012), Liu et al. (2017), and Rodríguez-Pose and Ezcurra (2010) tend to confirm an inequality-increasing effect of fiscal decentralization.

Quantitative research of inequalities takes place in a fairly narrow conceptual dimension, as it is strongly geared around the issue of divergence in economic development. This is especially surprising because the major promise of decentralization theory concerns the improved provision of local public goods and not primarily economic growth. There are some exceptions. With regard to the education sector, Arends (2017a) provides some evidence that federalism reform in Germany, which included the decentralization of teacher pay-setting competences to the federal states, may have increased disparities between the states in terms of educational poverty. With regard to healthcare, Montero-Granados et al. (2007) exploit the heterogeneous decentralization of healthcare competences over time in Spain in order to test for beta and sigma convergence in life expectancy and infant mortality between autonomous communities. They find no evidence for decentralization-induced decreasing regional inequalities. Decentralization may even further divergence. Paramita et al. (2018) provide data that suggest that healthcare decentralization in Indonesia led to a more equal distribution of some healthcare inputs such as physicians, hospitals, and hospital beds.

The omission of dealing with regional inequalities in service delivery outcomes is a major research gap. This is surprising given the prominence of these sectors in the decentralization discourse and in discussions on social justice. With regard to the broader literature on this issue, the evidence tends to confirm an inequality-enhancing effect of decentralization, in particular when taking account of findings from more recent research. The distinction between developed and developing economies is relevant as well.

\subsection{Does Decentralization Make Public Service Delivery Less Accountable?}

A major promise of decentralization enthusiasts is that fiscal decentralization improves local public service delivery by making local politicians and bureaucrats more responsive to the voter-taxpayers' demands, simply because public action is closer to the citizen (De Vries 2000, p. 202). 
Additionally, it is hoped that governments known for wasting or stealing local public resources will lose residents and businesses as they move to better-governed jurisdictions. This will reduce the tax base of poorly governed localities. Interjurisdictional competition would thus function as a remedy to issues such as overregulation or bribery, leading to preservation of favorable market conditions (Brennan and Buchanan 1980; Fan et al. 2009; Weingast 1995, p. 18). Yardstick competition is also presented as a factor in making citizens pressure local officials to improve the efficiency of local public service delivery to the maximum, and to refrain from wasting or stealing local resources (Allers and Elhorst 2005; Besley and Case 1995; Salmon 1987).

Even in the absence of strong local accountability relationships, the central government can impose sanctions on local governments when they do not comply with certain standards of financial and performance accountability (see Brinkerhoff 2004), not only through legal sanctions such as fines and jail, but also through the takeover of control by higher authorities, as has happened in the healthcare sector in Italy.

However, contrary to this rather optimistic view, various arguments have been brought forward suggesting that fiscal decentralization leads to deficient local accountability relations. One issue is that decentralization often implies an increase in the number of layers of government, which is seen to lead to "overgrazing" in terms of the formulation of new taxes and regulations at multiple governmental levels (Shleifer and Vishny 1993). What is more, it becomes more difficult to assign credit or blame to a specific level of government, an argument closely related to the issue of fiscal illusion (Kyriacou and Roca-Sagalés 2011, p. 191). Some scholars have argued that in a multilevel system, local government activities are not as easily monitored as activities carried out by the central government directly (Tabellini 2000), leading to a loss of accountability if minimum conditions related to central government oversight and sanctions as well as electoral accountability are not in place (Khan et al. 2017, p. 328). The loss of central government oversight (i.e., vertical accountability) may not be compensated by increased scrutiny through local citizens (i.e., horizontal accountability; Lessmann and Markwardt 2010).

For Bardhan and Mookherjee (2005, 2006), the extent of local capture and corruption is a fundamental flaw in the effectiveness of decentralization in improving service delivery. Indeed, the issue of corruption is probably the most prominently discussed issue in the field of accountability (Warren 2004). Skeptics consider that fiscal decentralization promotes corruption and local capture because of a higher degree of intimacy and frequency of interactions between local officials and local interest groups. The latter tend to be more cohesive than interest groups at the central level. Complementarily, local government officials are more likely to be captured than their central government counterparts because the latter are under stronger scrutiny due to their national relevance and because they are better paid and better qualified (Bardhan and Mookherjee 2000; Kyriacou et al. 2015, p. 91). The abovementioned issue of dividing responsibilities induced by fiscal decentralization can make it easier for local officials to conceal their involvement in corrupt practices such as embezzlement or collusion (Fan et al. 2009, p. 19). Administrative capacities and weak auditing and monitoring mechanisms are noted to be less developed at the local level. Moreover, in a decentralized system, incentives for local politicians to 
blame higher levels of government for their own poor performance exist (Neudorfer and Neudorfer 2015, p. 31). Also, the above-mentioned issue of fiscal illusion is considered a major risk to accountability (Rodden 2003).

Contrary to this view, there are authors who are generally skeptical about local officials handling large amounts of own-revenue funds, as these are often spent without central government oversight. Altunbaş and Thornton (2012, p. 79) argue that fiscal decentralization reduces corruption only when fiscal resources are still largely controlled by the central government, pointing to the need to incorporate institutional arrangements such as strong auditing and monitoring mechanisms in fiscal decentralization reforms. The issue of who should be controlling funds in order to avoid fiscal illusion remains an issue of contention.

Again, just as with the previous dimensions discussed, the empirical literature dealing with the effect of fiscal decentralization on accountability is inconclusive (Faguet 2017, p. 1674), very broad, and methodologically diverse (see Ivanyna and Shah 2011). There are, to my knowledge, no quantitative analyses dealing with the relationship between fiscal decentralization and accountability and corruption in public service delivery. This is especially true for the education and health sectors. Some qualitative discussions can be found. For example, Mitchell and Bossert (2010) review the impact of decentralization on health sector governance in six developing countries, arguing that the central government plays an important role in ensuring local government accountability toward reaching healthcare objectives, e.g., through earmarking central government transfers to specific healthcare dimensions. Yet Treisman (2007, p. 235) reasons that there is no clear-cut pattern with regard to the relationship between decentralization and corruption. The unclear empirical results support the notion (Bardhan and Mookherjee 2000, p. 139) that the effect of decentralization on corruption is mediated by a multitude of factors that are highly context-specific.

In summary, while the effect of decentralization on accountability and corruption is very widely discussed, there is little empirical (quantitative) work so far. Almost no evidence exists for the health and education sectors, which is astonishing because these sectors consume the bulk of public resources in many countries. The research gap is likely to be the result of the multidimensional nature of the concepts of accountability and corruption, which makes the emergence of a coherent field of research very difficult. This means that the major argument of bringing government service provision closer to the people and thus enhancing accountability cannot be resolved. Clearer evidence is needed, bearing in mind that a lack of accountability and corruption hint at fundamental deficiencies in democratic systems.

\section{Discussion: Risk Mitigation Strategies and Scope Conditions}

The arguments reviewed above suggest that there may be real dangers that put the expected benefits of decentralization reform in education and healthcare at risk. Are there any practical considerations to keep in mind when designing reforms aimed at localizing health and education policy? In this section I will present a number of factors and scope conditions related to the specific public service, the local context, 
and the design of fiscal relations that should be considered in order to minimize the risks of fiscal decentralization.

\subsection{On the Characteristics of the Public Service}

One important conclusion of the above review is that decentralization needs a service-specific and sector-specific approach, taking into account the unique set of challenges that local provision of a certain public good may entail. One key determinant is the technical complexity of the respective service. While the local dimension of rather unidimensional services such as road construction and maintenance is less contested, the impact of decentralization on education and healthcare performance is reviewed in such a critical manner because these sectors require a high degree of skilled human resources, capital investment, and technology. Attracting and correctly allocating skilled staff, planning hospitals, or investing in the latest technological inventions is likely to be more challenging to the subnational than to the central government (Byrkjeflot and Neby 2008; Ettelt et al. 2008; Mosca 2006). The technicity to a large part determines the potential strain on local management and planning capacities.

Technicity is strongly related to the degree to which scale economies are an issue. Healthcare inputs are likely to be more efficiently purchased or produced at the central government level and then distributed to the local level. Other sectors where inputs can also be produced locally may not need such a division of responsibilities (Hart and Welham 2016, p. 10). Clearly, scale economies can also be dealt with through horizontal strategies, in particular through cooperation among municipalities, or amalgamation, i.e., merging of smaller municipalities into larger ones (see Blom-Hansen et al. 2016).

Territorial effects are also strongly related to the magnitude of interjurisdictional spillovers and externalities. While some spillovers may be limited or easily controlled, for example in the area of public transport or electricity provision, other services seem to be fairly difficult to control. In education, the spillover discussion is related to the brain-drain hypothesis, with local governments providing highquality education, which in turn may lead to the out-migration of a well-qualified workforce to more attractive jurisdictions (Beine et al. 2001; Strathman 1994). Decentralization arrangements of public services with strong spillover effects should be subject to fiscal compensation mechanisms.

Prud'homme (1995) argues that the risk of tax competition can be minimized by focusing on decentralizing services that are chargeable, such as water or electricity. This way, the public service is to some extent privatized, and the financial burden lies on the actors that actually consume the public service. Mobile production factors or citizens who are concerned about the tax burden are prevented from migrating to other localities. Moreover, the risk of free-riding is diminished (Reynolds 2004). However, as the social importance criterion suggests, public services of high relevance to social justice, such as education and health, are often not financed through local fees in order to ensure access by all parts of the population.

One dimension to keep in mind when reflecting on the decentralization of a certain public service is its social importance. For example, it may be more convenient to 
experiment and accept a potential deterioration or increase in territorial inequalities of service delivery in nonessential services such as waste collection than in sectors crucial to human development such as health, education, or public security. In fact, while in some cases there may be decentralization of key sectors such as education, the central government may still reserve the right to ensure common education standards and try to prevent territorial segregation.

\subsection{On the Characteristics of the Context}

The characteristics of the level of government to which the service is to be decentralized are crucial as well. The "absorption capacity" of the receiving local context most likely determines a reform's success. One simple but important factor is the size of the locality. Functional federalism holds that in particular to avoid congestion of the consumption of a public service, but also to exploit economies of scale, the size of the population covered by a certain public service provision system is key (Ostrom et al. 1961). Some public services such as healthcare or education may have a larger optimal population size than others, e.g., public spaces. This is why functional federalism theory suggests that different classes of public services need different territorial boundaries, resulting in different and overlapping jurisdictions (Casella and Frey 1992). While this line of reasoning implies that the nature of the public service determines the size of the jurisdiction, the fact is that in most cases, territorial divisions are historically given and cannot be adjusted easily. Of course, population is not the only dimension of a jurisdiction's size. In fact, the extent of the territory, particularly in combination with population size, is an important factor to keep in mind when it comes to access to public services by those in remote areas. It may just be too costly to provide the service in rural, remote, and sparsely populated areas. However, in order to comply with the equity dimension of public service provision, most (developed) nations opt for making an extra effort to provide a certain public service in marginalized territories. Clearly, while territorial size is key, other geographic characteristics such as mountains or deserts can make service provision even more costly.

From the above discussion it also becomes clear that the context of local capacities must be carefully analyzed when considering decentralization reforms (Fiszbein 1997). Especially when decentralization is being pursued by means of one great step, local governments may be overwhelmed with the new tasks. This argument of absorption capacity relates to the capacity-building work that needs to be undertaken before decentralization reform takes place. Mechanisms to train, monitor, and professionalize local officials and processes are key (Levitas 2017, p. 41).

A key determinant of successful decentralization reform, and closely related to the issue of local capacities, is whether the local level provides for sufficiently strong accountability relationships between citizen-taxpayers and local officials. The challenges that place the benefits of decentralization at risk relate to a broader notion of accountability, for example with regard to the question of strong local media, local elections, or consultation processes, which ensure that local leaders act to further an efficient and equitable provision of public services. While research on the effect of decentralization on corruption is inconclusive, as discussed above, there 
is little doubt that preexisting deficient and weak local accountability makes it even more difficult to reach an efficient and equitable functioning of decentralized public sectors. One extreme case is the capturing of local governments through criminal organizations, as is the case in Mexico (Trejo and Ley 2019). Thus, accountability mechanisms should be strengthened before decentralization reform takes place.

Finally, and on a more general note, the evidence of the effect of decentralization on efficiency, equality, and accountability differs depending on whether decentralization takes place in a developed or developing country context. This has been argued by Hanushek et al. (2013) in terms of the issue of school autonomy. It is likely that the above-mentioned contextual conditions such as local capacities, geographic connectivity, and accountability mechanisms are highly correlated with the level of development.

\subsection{On the Design of Fiscal Relations}

The design of fiscal decentralization is a third key dimension to take into account. It can take on different forms: It can consist of a decentralization of competences to provide a particular service without passing down additional revenue autonomy and financing service provision through intergovernmental transfers instead. It can consist of decentralizing service provision competences without transferring any additional funds, pressuring local governments to raise their own revenues. Fiscal decentralization can consist of transferring both service provision and additional revenue-raising autonomy (Stegarescu 2005). While these topics have been discussed in detail elsewhere (Boadway and Shah 2009), with regard to the foregoing review of the dangers of decentralization for public service delivery, some factors need to be emphasized.

One major feature of many fiscal arrangements are equalization schemes, i.e., redistribution of fiscal resources from richer to poorer regions, which are seen to create a level playing field in unequal countries and to compensate for externalities (Liu et al. 2017, p. 254). Similarly, there is ample evidence that possible perverse incentives emanating from a strong reliance on intergovernmental transfers to finance local public good provision need to be kept in mind. As stressed above, the distinction between spending and own-revenue-based local financing is crucial. Transfer-based decentralization is likely to lead to fiscal illusion and irresponsible fiscal behavior by local governments. Arends (2017b) finds that while spending decentralization is making health sectors bigger and at the same time not leading to better health outcomes, tax-based decentralization does not have an effect on spending and may even improve outcomes and efficiency, a finding that confirms those of others (Jiménez-Rubio and García-Gómez 2017). In Poland, an unclear division of fiscal tasks caused a blame game between the national and the local governments about which level of government is underfunding the education sector (Levitas 2017, p. 39; Jeong et al. 2017). Letelier and Ormeño (2018) find that the higher the ratio of local own-revenues to total revenues, the better students' learning achievements in South Korea and Chile, respectively.

If education and health sectors are financed through local revenues, reformers have the choice between earmarked and non-earmarked taxes. Earmarking taxes 
to a specific sector can enhance accountability because it reduces fiscal illusion. Earmarking can also shelter the financing of these sectors from broader shocks to public revenue. However, they curtail local fiscal autonomy and can increase inequality when they contain a strong element of benefit taxation, i.e., people are taxed according to the benefits they receive from a public service, ultimately excluding poorer households from being able to afford the services (Hines 2000).

If decentralized health and education sectors are to be financed through federal transfers-for example, in order to equalize regional differences in sector performance, to establish common standards across all regions, or to prevent unhealthy competition between regions (Boadway and Shah 2009, p. 405-408) - the difference between earmarked and non-earmarked transfer schemes needs to be taken into account as well. While general-purpose grants that are not earmarked for spending in a specific policy area and that are distributed on the basis of a specific allocation formula imply substantial spending autonomy for local jurisdictions, they are usually less responsive to increasing expenditure needs. Especially in health and education, the constantly increasing demand for more and better services may not be matched with increasing resources from the central government, simply because the transfer scheme is not flexible enough (Boadway and Shah 2009, p. 297). If public services are financed through earmarked transfers, it is likely that resources will not be allocated in the most efficient way because local jurisdictions will not have total autonomy to spend according to local preferences. However, with these specific-purpose grants, the central government can push through political priorities that would otherwise not have received adequate attention from local governments. This is the case for the German Digitalpakt, through which the federal government provides resources to specifically promote digitization in German schools (Schneider 2019). Once reformers opt for transfer-based decentralization, innovative design elements should be considered, such as tying additional resources to compliance with performance targets ("performance-based transfers"; Boadway and Shah 2009, p. 314), which, when implemented in the context of solid statistical systems, can enhance vertical accountability relations.

One further issue that has to be kept in mind when designing decentralization reforms is the question of whether local governments should be able to borrow, in particular due to the bailout expectation already examined above. While deficit finance cannot be thoroughly discussed in the context of this article, it can be noted that there is general consensus that local borrowing autonomy should be restricted, depending on the specific context. Restrictions can range from strictly prohibiting deficit finance, to opening up deficit financing for capital investments, to permitting borrowing up to a certain debt-to-GDP ratio.

Table 1 summarizes the major arguments reviewed above.

\section{Conclusion}

International donor organizations, policy advisors, and scholars continue to promote decentralization reforms around the world. Countries in West and Central Africa, in Latin America, and in the Middle East are in the process of decentralizing important 
Table 1 Overview of arguments

\section{The rationale behind fiscal decentralization}

Tiebout sorting: Competition between local governments for optimal population size leads to differentiation of supply of public services (Tiebout 1956)

Preference matching: Local decision makers have superior knowledge about local preferences and tailor public services accordingly (Oates 1972)

Yardstick competition: Voters/taxpayers compare performance between local governments and hold politicians to account (Breton 1987; Salmon 1987)

Laboratories of experimentation: Local governments serve as a space for experimentation, which eventually may be scaled up to the national level (Vanberg and Kerber 1994)

\section{Three dangers to service provision}

\section{Inefficient service provision}

Interjurisdictional spillovers (Olson 1969)

Race to the bottom

(Cumberland 1981)

Flypaper effect

(Courant et al. 1979)

Soft budget constraints

(Kornai et al. 2003)

Fiscal illusion

(Weingast et al. 1981)

Absent scale economies

(Blom-Hansen et al. 2016)

Weak local administrative capacities

(Tanzi 1996)

\section{Risk mitigation strategies and scope conditions}

On the public service

Service-specific and sector-

specific approach needed

Technical complexity can overburden localities

Loss of scale economies needs to be prevented

Interjurisdictional spillovers need to be compensated

Chargeability helps to avoid unhealthy competition

Social significance of public services makes experimentation politically risky
Unequal service provision

Absence of equalizing institutions

(Prud'homme 1995)

Advantageous initial conditions

(Cai and Treisman 2005)

Favorable tax conditions of privileged regions

(Prud'homme 1995)

Agglomeration effects

(Zhang 2006)

Power imbalances

(Liu et al. 2017; Rodríguez-

Pose and Gill 2005)

$-$

On the context

Different optimal population sizes for different services

Remote areas imply higher investment in infrastructure

Local capacities can be overburdened when decentralizing complex services

Local accountability should be strengthened before decentralization reform

Relevance of risks of decentralization differs depending on level of development
Unaccountable service provision

Fiscal illusion

(Weingast et al. 1981)

Overgrazing

(Shleifer and Vishny 1993)

Weak central government oversight (Lessmann and Markwardt 2010)

Vested interests

(Bardhan and Mookherjee 2000)

Weak local auditing

(Prud'homme 1995)

Deficient local accountability mechanisms

(Blair 2000)

\section{On the design of fiscal relations}

Equalization schemes can promote territorial equality and internalize spillovers

Reliance on intergovernmental transfers decreases efficiency

Earmarked local taxes can enhance accountability but may decrease efficiency and equality

Earmarked transfers can be important to promote national priorities but may decrease efficiency

Innovative design elements can promote results orientation of local governments

Local deficit finance should be regulated in order to prevent bailouts from happening 
functions to lower levels of government-oftentimes accompanied and encouraged by external actors. Without a doubt, the underlying rationale is not always confined to the efficiency promise of fiscal decentralization, but has more fundamental justifications such as enhancing democratic governance and preserving and protecting the rights of minority groups.

However, the foregoing review suggests that it is by no means clear that fiscal decentralization reform brings about the suggested merits. The review shows that even the most advanced economies are struggling hard to benefit from decentralization, ultimately engaging in processes of recentralization. It is by no means farfetched to assume that if countries like Norway or Ireland experience disadvantages in full health sector decentralization, countries in severe disarray such as Iraq, where decentralization is promoted by international donor organizations (see World Bank 2016), will encounter even more fundamental challenges with regard to weak local administrative and management capacities, budget limitations, and accountability.

The overarching conclusion is that much depends on the specific institutional and policy design of fiscal decentralization. In fact, the literature on fiscal decentralization and public service delivery provides a number of clues that are important to bear in mind in order to avoid the dangers of decentralization. Following the principle "a danger foreseen is half avoided!," policy makers must be aware of the fact that the success of fiscal decentralization depends on a multitude of factors, which need to be closely monitored.

Funding Open Access funding provided by Projekt DEAL.

Open Access This article is licensed under a Creative Commons Attribution 4.0 International License, which permits use, sharing, adaptation, distribution and reproduction in any medium or format, as long as you give appropriate credit to the original author(s) and the source, provide a link to the Creative Commons licence, and indicate if changes were made. The images or other third party material in this article are included in the article's Creative Commons licence, unless indicated otherwise in a credit line to the material. If material is not included in the article's Creative Commons licence and your intended use is not permitted by statutory regulation or exceeds the permitted use, you will need to obtain permission directly from the copyright holder. To view a copy of this licence, visit http://creativecommons.org/licenses/by/4. $0 /$.

\section{References}

Adam, Antonis, Manthos D. Delis, and Pantelis Kammas. 2014. Fiscal decentralization and public sector efficiency: evidence from OECD countries. Economics of Governance 15(1):17-49.

Allers, Maarten A., and J. Paul Elhorst. 2005. Tax mimicking and yardstick competition among local governments in the Netherlands. International Tax and Public Finance 12(4):493-513.

Altunbaş, Yener, and John Thornton. 2012. Fiscal decentralization and governance. Public Finance Review 40(1):66-85.

Aray, Henry. 2018. More on decentralization and economic growth. Papers in Regional Science 97(4):971-993.

Arends, Helge. 2017a. Equal living conditions vs. cultural sovereignty? Federalism reform, educational poverty and spatial inequalities in Germany. Publius: The Journal of Federalism 47(4):673-706.

Arends, Helge. 2017b. More with less? Fiscal decentralization, public health spending and health sector performance. Swiss Political Science Review 23(2):144-174.

Barankay, Iwan, and Ben Lockwood. 2007. Decentralization and the productive efficiency of government: evidence from Swiss cantons. Journal of Public Economics 91(5-6):1197-1218.

Bardhan, Pranab, and Dilip Mookherjee. 2000. Capture and governance at local and national levels. The American Economic Review 90(2):135-139. 
Bardhan, Pranab, and Dilip Mookherjee. 2005. Decentralizing antipoverty program delivery in developing countries. Journal of Public Economics 89(4):675-704.

Bardhan, Pranab, and Dilip Mookherjee. 2006. Decentralisation and accountability in infrastructure delivery in developing countries. The Economic Journal 116:101-127.

Beine, Michel, Frédéric Docquier, and Hillel Rapoport. 2001. Brain drain and economic growth: theory and evidence. Journal of Development Economics 64(1):275-289.

Bel, Germà, and Mildred E. Warner. 2016. Factors explaining inter-municipal cooperation in service delivery: a meta-regression analysis. Journal of Economic Policy Reform 19(2):91-115.

Besley, Timothy, and Anne Case. 1995. Does electoral accountability affect economic policy choices? Evidence from gubernatorial term limits. The Quarterly Journal of Economics 110(3):769-798.

Blair, Harry. 2000. Participation and accountability at the periphery: democratic local governance in six countries. World Development 28(1):21-39.

Blom-Hansen, Jens, Kurt Houlberg, Søren Serritzlew, and Daniel Treisman. 2016. Jurisdiction size and local government policy expenditure: assessing the effect of municipal amalgamation. American Political Science Review 110(4):812-831.

Boadway, Robin, and Anwar Shah. 2009. Fiscal federalism. New York: Cambridge University Press.

Brennan, Geoffrey, and James Buchanan. 1980. The power to tax: analytic foundations of a fiscal constitution. Cambridge: Cambridge University Press.

Breton, Albert. 1987. Towards a theory of competitive federalism. Villa Colombella Papers on Federalism Proceedings of the Seminar 3(1-2):263-329.

Brinkerhoff, Derick W. 2004. Accountability and health systems: toward conceptual clarity and policy relevance. Health Policy and Planning 19(6):371-379.

Busemeyer, Marius R. 2008. The impact of fiscal decentralisation on education and other types of spending. Swiss Political Science Review 14(3):451-481.

Byrkjeflot, Haldor, and Simon Neby. 2008. The end of the decentralised model of healthcare governance? Journal of Health Organization and Management 22(4):331-349.

Cai, Hongbin, and Daniel Treisman. 2005. Does competition for capital discipline governments? Decentralization, globalization, and public policy. The American Economic Review 95(3):817-830.

Canaleta, Carlos Gil, Pedro Pascual Arzoz, and Manuel Rapun Garate. 2004. Regional economic disparities and decentralisation. Urban Studies 41(1):71-94.

Casella, Alessandra, and Bruno Frey. 1992. Federalism and clubs. European Economic Review 36(2): 639-646.

Channa, Anila, and Jean-Paul Faguet. 2016. Decentralization of health and education in developing countries: a quality-adjusted review of the empirical literature. The World Bank Research Observer 31(2):199-241.

Clark, Damon. 2009. The performance and competitive effects of school autonomy. Journal of Political Economy 117(4):745-783.

Cobos Muñoz, Daniel, Paloma Merino Amador, Laura Monzon Llamas, David Martinez Hernandez, et al, 2017. Decentralization of health systems in low and middle income countries: a systematic review. International Journal of Public Health 62(2):219-229.

Cooper, William W., Lawrence M. Seiford, and Kaoru Tone. 2006. Introduction to data envelopment analysis and its uses. New York: Springer.

Courant, Paul N., Edward M. Gramlich, and Daniel L. Rubinfeld. 1979. The stimulative effects of intergovernmental grants: or why money sticks where it hits. In Fiscal federalism and grants-in-aid, ed. Peter Mieszkowski, William H. Oakland, 5-21. Washington: The Urban Institute.

Cumberland, John. 1981. Efficiency and equity in interregional environmental management. Review of Regional Studies 2:1-9.

Dwicaksono, Adenantera, and Ashley M. Fox. 2018. Does decentralization improve health system performance and outcomes in low- and middle-income countries? A systematic review of evidence from quantitative studies. The Milbank Quarterly 96(2):323-368.

Díaz-Cayeros, Alberto, Beatriz Magaloni, and Alexander Ruiz-Euler. 2014. Traditional governance, citizen engagement, and local public goods: evidence from Mexico. Decentralization and Governance 53(Supplement C):80-93.

Ettelt, Stefanie, Ellen Nolte, Athanasios Nikolentzos, and Nicholas Mays. 2008. Decision-making in health care: Roles and responsibilities at local, regional and national level. London: A report by the London School of Hygiene \& Tropical Medicine.

Ezcurra, Roberto, and Pedro Pascual. 2008. Fiscal decentralization and regional disparities: evidence from several European Union countries. Environment and Planning A: Economy and Space 40(5):1185-1201. 
Faguet, Jean-Paul. 2017. Transformation from Below in Bangladesh: decentralization, local governance, and systemic change. Modern Asian Studies 51(6):1668-1694.

Fan, C. Simon, Lin Chen, and Daniel Treisman. 2009. Political decentralization and corruption: evidence from around the world. Journal of Public Economics 93(1):14-34.

Fiszbein, Ariel. 1997. The emergence of local capacity: lessons from Colombia. World Development 25(7):1029-1043.

Goel, Rajeev K., Ummad Mazhar, Michael A. Nelson, and Rati Ram. 2017. Different forms of decentralization and their impact on government performance: Micro-level evidence from 113 countries. Economic Modelling 62:171-183.

Goodspeed, Timothy J. 2002. Bailouts in a federation. International Tax and Public Finance 9(4):409-421.

Hanushek, Eric A., Susanne Link, and Ludger Woessmann. 2013. Does school autonomy make sense everywhere? Panel estimates from PISA. Journal of Development Economics 104:212-232.

Hart, Tom, and Brym Welham. 2016. Fiscal decentralisation: a public financial management introductory guide. London: Overseas Development Institute.

Hines, James R. 2000. What is benefit taxation? Journal of Public Economics 75(3):483-492.

Hines, James R., and Richard H. Thaler. 1995. Anomalies: the flypaper effect. The Journal of Economic Perspectives 9(4):217-226.

Inman, Robert P., and Daniel L. Rubinfeld. 1997. Rethinking federalism. The Journal of Economic Perspectives 11(4):43-64.

Ivanyna, Maksym, and Anwar Shah. 2011. Decentralization and corruption: new cross-country evidence. Environment and Planning C: Government and Policy 29(2):344-362.

Jeong, Dong Wook, Lee Ho Jun, and Sung Kyung Cho. 2017. Education decentralization, school resources, and student outcomes in Korea. International Journal of Educational Development 53:12-27.

Jiménez-Rubio, Dolores, and Pilar García-Gómez. 2017. Decentralization of health care systems and health outcomes: Evidence from a natural experiment. Social Science \& Medicine 188:69-81.

Khan, Qaiser, Jean-Paul Faguet, and Alemayehu Ambel. 2017. Blending top-down federalism with bottomup engagement to reduce inequality in Ethiopia. World Development 96:326-342.

Kornai, János, Eric Maskin, and Gérard Roland. 2003. Understanding the soft budget constraint. Journal of Economic Literature 41(4):1095-1136.

Kostka, Genia, and Jobst Fiedler. 2016. Large Infrastructure Projects in Germany. Between Ambition and Realities. Cham: Palgrave Macmillan.

Kunce, Mitch, and Jason F. Shogren. 2007. Destructive interjurisdictional competition: Firm, capital and labor mobility in a model of direct emission control. Ecological Economics 60(3):543-549.

Kyriacou, Andreas P., and Oriol Roca-Sagalés. 2011. Fiscal decentralization and government quality in the OECD. Economics Letters 111(3):191-193.

Kyriacou, Andreas P., Leonel Muinelo-Gallo, and Oriol Roca-Sagalés. 2015. Fiscal decentralization and regional disparities: the importance of good governance. Papers in Regional Science 94(1):89-107.

Lessmann, Christian. 2009. Fiscal decentralization and regional disparity: evidence from cross-section and panel data. Environment and Planning A: Economy and Space 41(10):2455-2473.

Lessmann, Christian. 2012. Regional inequality and decentralization: an empirical analysis. Environment and Planning A 44(6):1363-1388.

Lessmann, Christian, and Gunther Markwardt. 2010. One size fits all? Decentralization, corruption, and the monitoring of bureaucrats. World Development 38(4):631-646.

Letelier, Leonardo, and Hector Ormeño. 2018. Education and fiscal decentralization. The case of municipal education in Chile. Environment and Planning C: Politics and Space 36(8):1499-1521.

Levitas, Anthony. 2017. Local government reform as state building: what the Polish case says about "decentralization". Studies in Comparative International Development 52(1):23-44.

Litvack, Jennie, Ahmad Junaid, and Richard M. Bird. 1998. Rethinking decentralization in developing countries. Washington D.C.: World Bank.

Liu, Yongzheng, Jorge Martinez-Vazquez, and Alfred M. Wu. 2017. Fiscal decentralization, equalization, and intra-provincial inequality in China. International Tax and Public Finance 24(2):248-281.

Martinez-Vazquez, Jorge, and Andrey Timofeev. 2010. Choosing between centralized and decentralized models of tax administration. International Journal of Public Administration 33(12-13):601-619. https://doi.org/10.1080/01900692.2010.514467.

Martinez-Vazquez, Jorge, Santiago Lago-Peñas, and Agnese Sacchi. 2017. The impact of fiscal decentralization: a survey. Journal of Economic Surveys 31(4):1095-1129.

Martínez, Yolanda Ubago, Pedro Pascual Arzoz, and Belén Iráizoz Apezteguía. 2018. Does decentralization contribute to efficiency? Evidence from OECD countries. Applied Economics 50(7):726-742. 
Mauro, Marianna, Anna Maresso, and Annamaria Guglielmo. 2017. Health decentralization at a dead-end: towards new recovery plans for Italian hospitals. Health Policy 121(6):582-587.

Mitchell, Andrew, and Thomas J. Bossert. 2010. Decentralisation, governance and health-system performance: "where you stand depends on where you sit". Development Policy Review 28(6):669-691.

Montero-Granados, Roberto, Juan de Dios Jiménez, and José Martín. 2007. Decentralisation and convergence in health among the provinces of Spain (1980-2001). Social Science \& Medicine 64(6):1253-1264.

Mosca, Ilaria. 2006. Is decentralisation the real solution?: A three country study. Health Policy 77(1): 113-120.

Musgrave, Richard. 1959. The theory of public finance. New York: McGraw-Hill.

Naper, Linn Renée. 2010. Teacher hiring practices and educational efficiency. Economics of Education Review 29(4):658-668.

Neudorfer, Benjamin, and Natascha S. Neudorfer. 2015. Decentralization and political corruption: disaggregating regional authority. Publius: The Journal of Federalism 45(1):24-50.

Oates, Wallace E. 1968. The theory of public finance in a federal system. The Canadian Journal of Economics $1(1): 37-54$.

Oates, Wallace E. 1972. Fiscal federalism. New York: Harcourt Brace Jovanovich.

Oates, Wallace E. 1985. Searching for leviathan: an empirical study. The American Economic Review 75(4):748-757.

Oates, Wallace E. 1999. An essay on fiscal federalism. Journal of Economic Literature 37:1120-1149.

Oates, Wallace E. 2005. Toward A second-generation theory of fiscal federalism. International Tax and Public Finance 12:349-373.

Olson, Mancur, Jr.. 1969. The principle of "fiscal equivalence": the division of responsibilities among different levels of government. The American Economic Review 59(2):479-487.

Ostrom, Elinor. 1990. Governing the commons. Cambridge: Cambridge University Press.

Ostrom, Vincent, Charles M. Tiebout, and Robert Warren. 1961. The organization of government in metropolitan areas: a theoretical inquiry. The American Political Science Review 55(4):831-842.

Paramita, Sekar Ayu, Chiho Yamazaki, Elsa Pudji Setiawati, and Hiroshi Koyama. 2018. Distribution trends of Indonesia's health care resources in the decentralization era. The International Journal of Health Planning and Management 33(2):e586-e596.

Pierson, Paul. 1995. Fragmented welfare states: federal institutions and the development of social policy. Governance 8(4):449-478.

Prawda, Juan. 1993. Educational decentralization in Latin America: lessons learned. International Journal of Educational Development 13(3):253-264.

Prud'homme, Rémy. 1995. The dangers of decentralization. The World Bank Research Observer 10(2):201-220.

Qian, Yingyi, and Barry R. Weingast. 1997. Federalism as a Commitment to Perserving Market Incentives. The Journal of Economic Perspectives 11(4):83-92.

Ramírez, Juan Mauricio, Yadira Díaz, and Juan Guillermo Bedoya. 2017. Property tax revenues and multidimensional poverty reduction in Colombia: a spatial approach. World Development 94:406-421.

Reynolds, Laurie. 2004. Taxes, fees, assessments, dues, and the get what you pay for model of local government. Florida Law Review 56:373-446.

Rodden, Jonathan. 2003. Reviving leviathan: fiscal federalism and the growth of government. International Organization 57(04):695-729.

Rodríguez-Pose, Andrés, and Roberto Ezcurra. 2010. Does decentralization matter for regional disparities? A cross-country analysis. Journal of Economic Geography 10(5):619-644.

Rodríguez-Pose, Andrés, and Nicholas Gill. 2005. On the "economic dividend" of devolution. Regional Studies 39(4):405-420.

Rondinelli, Dennis A., James S. McCullough, and Ronald W. Johnson. 1989. Analysing decentralization policies in developing countries: a political-economy framework. Development and Change 20(1):57-87.

Rubinfeld, Daniel L. 1987. Chapter 11 the economics of the local public sector. In Handbook of Public Economics, ed. Alan J. Auerbach, Martin Feldstein, 571-645. Amsterdam: Elsevier.

Salmon, Pierre. 1987. Decentralisation as an Incentive Scheme. Oxford Review of Economic Policy 3(2):24-43.

Saltman, Richard B. 2008. Decentralization, re-centralization and future European health policy. European Journal of Public Health 18(2):104-106.

Samuelson, Paul A. 1954. The pure theory of public expenditure. Review of Economics and Statistics 36:387-389. 
Samuelson, Paul A. 1955. Diagrammatic exposition of a theory of public expenditure. The Review of Economics and Statistics 37(4):350-356.

Scheiter, Katharina, and Andreas Lachner. 2019. DigitalPakt - was nun? Eine Positionierung aus Sicht der Lehr-Lernforschung. Unterrichtswissenschaft 47(4):547-564.

Schmidt, Manfred G. 2007. Die öffentlichen und privaten Bildungsausgaben Deutschlands im internationalen Vergleich. Zeitschrift für Staats- und Europawissenschaften 2(1):7-31.

Schneider, Kerstin. 2019. Wettbewerb and Vielfalt? Der Bildungsföderalismus in Deutschland. Ifo Schnelldienst 72(3):6-9.

Shankar, Raja, and Anwar Shah. 2003. Bridging the economic divide within countries: a scorecard on the performance of regional policies in reducing regional income disparities. World Development 31(8):1421-1441.

Shleifer, Andrei, and Robert W. Vishny. 1993. Corruption. The Quarterly Journal of Economics 108(3):599-617.

Stegarescu, Dan. 2005. Public sector decentralisation: measurment concepts and international trends. Fiscal Studies 26(3):301-333.

Strathman, James G. 1994. Migration, benefit Spillovers and state support of higher education. Urban Studies 31(6):913-920.

Tabellini, Guido. 2000. Constitutional determinants of government spending. CESifo Working Paper Series 265.

Tanzi, Vito. 1996. Fiscal federalism and decentralisation: a review of some efficiency and macroeconomic aspects. In Annual world bank conference on development economics 1995, 295-315. Washington D.C.: Annual World Bank Conference on Development Economics.

Tiebout, Charles M. 1956. A pure theory of local expenditures. Journal of Political Economy 64(5): 416-424.

Treisman, Daniel. 2007. What have we learned about the causes of corruption from ten years of crossnational empirical research? Annual Review of Political Science 10(1):211-244.

Trejo, Guillermo, and Sandra Ley. 2019. Multilevel partisan conflict and drug violence in Mexico. In Inside countries: Subnational research in comparative politics, ed. Agustina Giraudy, Eduardo Moncada, and Richard Snyder, 181-213. Cambridge: Cambridge University Press.

Turner, Ed, and Carolyn Rowe. 2015. A race to the top, middle or bottom? The consequences of decentralisation in Germany. Manchester: Institute for Policy Research North.

Vanberg, Viktor, and Wolfgang Kerber. 1994. Institutional competition among jurisdictions: an evolutionary approach. Constitutional Political Economy 5(2):193-219.

De Vries, Michiel S. 2000. The rise and fall of decentralization: a comparative analysis of arguments and practices in European countries. European Journal of Political Research 38(2):193-224.

Warren, Mark E. 2004. What does corruption mean in a democracy? American Journal of Political Science 48(2):328-343.

Weingast, Barry R. 1995. The economic role of political institutions: market-preserving federalism and economic development. Journal of Law and Economic Organization 11:1-31.

Weingast, Barry R., Kenneth A. Shepsle, and Christopher Johnsen. 1981. The political economy of benefits and costs: a neoclassical approach to distributive politics. Journal of Political Economy 89(4):642-664.

World Bank. 2016. Decentralization and subnational service delivery in Iraq: status and way forward. Washington D.C.: World Bank.

Zhang, Xiaobo. 2006. Fiscal decentralization and political centralization in China: Implications for growth and inequality. Analyzing the Socioeconomic Consequences of Rising Inequality in China 34(4):713-726. 